\title{
Peer Review in Carnegie Research Libraries
}

\author{
Joan M. Leysen and William K. Black
}

The review of librarians by their peers is an elemental factor in advancement and continuing appointment. This article reports the results of a survey on structure, support, and expectations in place for peer review of librarians. The authors provide comparisons to previous research and discuss new information on the value placed on individual contributions in the review process. Librarian status is reviewed to uncover important differences in the specific structure of the review process and in how professional activities are weighed.

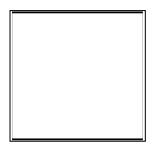

aculty performance review systems are being reexamined today, both on academic campuses and by professional associations. Issues such as faculty workload, accountability, tenure, and posttenure review are starting to engender discussions about the role of faculty and the assessment of their contributions to the academic enterprise. Initiatives such as New Pathways: Faculty Careers and Employment for the 21st Century, a project sponsored by the American Association of Higher Education (AAHE), are exploring tenure's benefits, liabilities, and alternatives. ${ }^{1}$ Within the library profession, a recent report from the ACRL, "The Redefining Scholarship Project: A Draft Report," is helping to form the discussion for librarians by categorizing various activities and broadening the definition of scholarship. ${ }^{2}$

Although peer review is a timely issue on university campuses, it has received minimal coverage in the library literature, perhaps because of the confidential nature of the review process. If we are to have an informed discourse on the contributions of librarians within the academic institution, "The scholar should learn about the review process: how often, how formal, and how important the various reviews may be; the type of documentation that is expected, so that it can be assembled thoughtfully over time; the steps the committee follows; the criteria that are used to assess the quality of one's scholarly work; and the relative weighing of various activities." 3

To address these issues in more detail, the authors conducted a study to examine the peer review structure and process for advancement and continuing appointment for librarians at Carnegie Research institutions. ${ }^{4,5}$ This category of institution was chosen because it is a well-defined group that has a shared emphasis on research and corresponds to a selection of institutions used in earlier studies. ${ }^{6}$ Given this shared focus on research, are there similarities in the structure and process of peer review at these institutions? Are there differences in the values these institutions place on librar-

Joan M. Leysen is Monographs Cataloger and Assistant Professor in Parks Library at Iowa State University; e-mail: jleysen@iastate.edu. William K. Black is Administrative Services Librarian and Associate Professor in Todd Library at Middle Tennessee State University; e-mail: wblack@library.mtsu.edu. 
ian contributions in support of scholarship and service? What, if any, significance does faculty status for librarians have in these decisions? How do these data expand on the findings of earlier studies? Answers to these questions can inform our professional dialog and provide guidance for dealing with issues of advancement and continuing appointment in the research library community.

\section{Background}

As librarians manage knowledge resources and contribute to scholarly activities and professional service, their contributions are ordinarily assessed through some form of regular review process that evaluates performance, offers suggestions for future development, and coordinates job performance with recognition and reward. Often this assessment consists of an overview of performance carried out by the supervisor and of a review, generally conducted by peers, governing advancement and/or continuing appointment.

According to Judy Horn, peer review is practiced in 67 percent of the members of the Association of Research Libraries

\section{They mailed surveys to library administrators at 125 Carnegie Research institutions (88 Research I and 37 Research II).}

(ARL), usually more often in institutions where librarians hold faculty status. ${ }^{7}$ Horn and Karen F. Smith credited the 1972 Standards for Faculty Status for Colleges and University Librarians with influencing the adoption of peer review by the majority of the institutions they surveyed. ${ }^{8}$ These standards state that the review process for librarians should include "appraisal by a committee of peers who have access to all available evidence." ${ }^{\prime 9}$ Although peer review differs from the supervisor's assessment (normally performed on an annual basis), it must be consistent with such a review in terms of what it measures and the advice it provides. The importance of the documentation reviewed by the peer group and the value placed on various types of scholarly activity in the review process are significant elements of this article.

Betsy Park and Robert Riggs found that an evaluation of a candidate's scholarly research and publication activity is an important part of the evidence reviewed by the peer group, particularly at institutions where librarians hold faculty status or at "research, doctorate-granting, and comprehensive universities." ${ }^{10,11}$ Several studies have identified the types of publications accepted in library promotion and tenure review and the criteria for assessing these publications. ${ }^{12,13}$ There have been no studies on the importance assigned to various types of scholarly activity in research libraries and no full discussions in the literature on how contributions in electronic form by librarians are assessed.

\section{Methodology}

In May 1996, the authors surveyed libraries at Carnegie Research I and II institutions to determine the structure and systems in place for advancement and continuing appointment and how the status of librarians affects the process and the requirements. They mailed surveys to library administrators at 125 Carnegie Research institutions (88 Research I and 37 Research II). The survey questions collected information on the structure of the peer review process for advancement and continuing appointment and on the documentation, criteria, and support for this process. In addition, information on the rank, appointment, and status of librarians was requested. The survey items incorporated factual data with opinions. Instructions to participants requested that opinion questions be answered from the library administrator's point of view. Quantitative data could be supplied by other members of the library staff. A follow-up mailing or e-mail correspondence was sent to those who did not respond initially.

\section{Findings}

Of the 125 surveys distributed, a total of eighty-one $(65 \%)$ were returned. This in- 
cluded fifty-six $(69 \%)$ responses from Carnegie I and twenty-five (31\%) from Carnegie II institutions. Sixty-three (78\%) of the surveys returned were from institutions that are also members of the ARL; seventeen $(21 \%)$ came from private institutions. Not every respondent answered every question. In cases where this is significant, the number of respondents is given in parentheses.

\section{Status of Librarians}

Based on ACRL guidelines, forty-three respondents indicated that the majority of librarians at their institutions have faculty status. ${ }^{14,15}$ Thirty-five libraries have some form of academic status. In some cases, written comments revealed that librarians met most of the elements of the ACRL criteria for faculty status but did not have tenure or did not receive "equitable compensation and benefits."

At 77 percent $(n=78)$ of the institutions responding, librarians have a twelvemonth appointment. Although no libraries reported wholesale adoption of work schedulesidentical to the teaching faculty, 22 percent reported the existence of ninemonth contracts for some of their librarians.

Librarians are assigned rank equal to that of the teaching faculty at twentyeight institutions (35\%). With one exception, these same institutions offered faculty status with tenure or continuing appointment and advancement in rank. Twenty-five institutions (31\%) reported "equivalent rank," sixteen (20\%) reported "numerical rank," and ten (12\%) reported that no such rank is used for their librarians. ${ }^{16}$ Two institutions have both faculty and academic rank.

\section{Review Process}

\section{Structure}

Almost all the survey respondents indicated that there is involvement in the review process by the library director, a library committee, and a university official-most often the chief academic officer and frequently the president. Regardless of whether librarians hold faculty or academic status, survey responses show a high response rate for involvement of the library director and a library committee in the review process. The largest difference between those institutions with faculty status and those without lies in the use of a university committee to review candidates for continuing appointment. A university committee is included in the peer review process more often in institutions that provide faculty status for their librarians $(n=36)$ than in other environments $(n=23)$ where librarians have academic or some other status (72\% and $17 \%$, respectively).

In situations where librarians hold faculty status, a library peer review committee is used at 98 percent of the libraries. This committee is usually elected rather than appointed. Appointed committees are twice as likely to be used in libraries without faculty status. Of the total respondents with faculty status, 83 percent limit review committee membership to certain rank or status and contain membership that includes an individual above the department head level. Most committees report to the library director. The difference between librarians with faculty status and the other respondents is in the creation of the library review committee.

\section{Documentation}

Institutions require candidates for advancement or continuing appointment to provide the review team with documentation of accomplishments. This frequently includes a vita, copies of publications, works in progress, and names of references. Some institutions ask candidates for self-assessments describing outstanding contributions, evaluations from students, and copies of the annual performance evaluation.

The review team makes an assessment of candidates based on this documentation. The team may solicit more information through additional letters of reference. In some cases, the individuals chosen as references will be unknown to the candidates.

Library administrators were asked to rate the importance of this documentation in the review process on a scale ranging 
from "very important" to "not important." Letters of reference from the supervisor, annual performance evaluations, and a candidate's statement of accomplishments were seen as "very important" by more than 50 percent of the survey respondents. More than half of the respondents felt that copies of publications, projects, and significant letters of support recognizing assistance were "very important" or "important." Nearly half (49\%) of the responding institutions use formal student evaluations in the review process, and 32 percent find them to be important in assessing librarian performance.

Almost 30 percent $(n=75)$ of the library administrators indicated there has been a greater emphasis on publication in the past five years.

Almost two-thirds of the respondents $(\mathrm{n}=75)$ felt that review by individuals outside the institution was "very important" or "important" - 77 percent of faculty status institutions and 51 percent (n $=29)$ of others. About one-third $(n=71)$ of the administrators indicated that letters from individuals unknown to the candidate have importance in their review process. These references are considered more important at institutions where librarians hold faculty status $(42 \%)$. Eighteen percent $(n=28)$ of the non-faculty-status institutions value references unknown to the candidate.

\section{Criteria}

The survey queried activities in the research arena and participation in professional organizations, university committees, and community organizations. Almost 80 percent $(n=73)$ of the administrators indicated that service in professional associations is required, and 73 percent require service on university committees. Only 28 percent $(n=72)$ look at community service in their reviews. Although service expectations exist at both faculty and nonfaculty institutions, such activities are stressed more at libraries with faculty status. Seventy-two percent $(n=75)$ of the administrators indicated that service expectations have not changed in the past five years.

Almost 30 percent $(n=75)$ of the library administrators indicated there has been a greater emphasis on publication in the past five years. Publication is now required for promotion/advancement in 45 percent $(n=64)$ of the libraries responding. This increases to 68 percent when considering only faculty status institutions. In continuing appointment cases alone, it drops to 38 percent for all institutions. Although 59 percent of the faculty status institutions require publication for continuing appointment, none of the nonfaculty institutions do. Written comments revealed that in many institutions without faculty status, publication is only one method of exhibiting success. Although publication is often welcomed in these institutions, it is not required at the lower ranks. In faculty status environments, publication is more often an essential ingredient of performance for all ranks.

\section{Assessment}

Interestingly, the importance attributed to certain activities in the review process is similar in many instances for those librarians with faculty status and those with some other status (see figure 1). Elements such as refereed articles, books, and journal editorship received higher "very important" scores in the faculty status group, but responses from both status types rate these activities highly.

The most highly valued contributions in the review process at libraries with faculty status include papers presented at national meetings, national committee service, refereed journal articles, journal and book editorship, and books authored. In only six institutions are singleauthored publications specifically required, as opposed to multi-authored works. Written comments indicate that attention is paid to the balance of singleauthored and coauthored works. In one case, several coauthored works would be acceptable for the single-author requirement. 


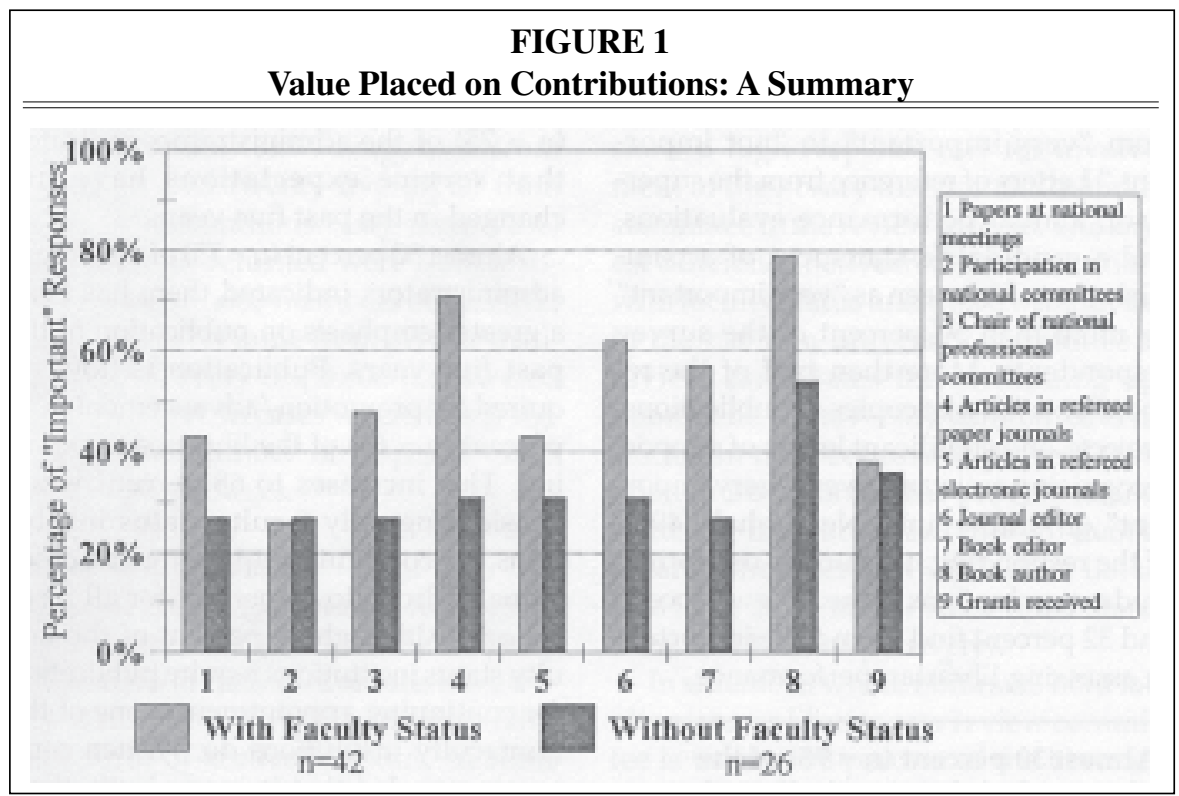

For librarians without faculty status, percentages are spread more broadly across the five rankings ("very important," "important," "useful," "not useful," and "not applicable"). Therefore, highly valued activities show lower percentage scores in the "important" ranges but are still major components of the review process. This reflects broader opportunities for contribution in nonfaculty institutions. These categories are similar to the responses for the faculty status group and include national papers and committees, refereed articles, editorship, books authored, and grants received.

The greatest difference between faculty status and non-faculty-status institutions occurs in the weight placed on authorship and editorship, and the preference for activities at the national level. Faculty status institutions show a much higher expectation for scholarly works in refereed journals. The highest scores for the nonfaculty group were spread across a number of activities that could qualify for tenure. These included professional participation at the state, regional, or national level; works in refereed publications; editorships; grants received; and other creative works such as computer applications, exhibits with catalogs, creation of
Web sites, or service as an Internet list owner. Although these activities are important in the group of faculty status libraries, they do not receive nearly the level of support for being considered tenurable activities on their own.

\section{Faculty status institutions show a much higher expectation for schol- arly works in refereed journals.}

Library administrators were asked to comment on contributions in electronic format. This includes articles in electronic journals, creation of Web sites, service as an Internet list owner, and works that involve creative application. Of these categories, articles in electronic journals are rated most important. Creating Web sites is considered of value by 81 percent $(n=$ 70) of the respondents. Those responding from non-faculty-status institutions consider Web design more valuable than those responding from faculty status institutions. Serving as a listserv owner is considered "useful" or "important" by 63 percent $(n=70)$ of the respondents, but none rate it as "very important."

\section{Institutional Support}

Research libraries support professional 


\begin{tabular}{|c|c|c|c|c|c|}
\hline \multicolumn{6}{|c|}{$\begin{array}{c}\text { TABLE } 1 \\
\text { Institutional Support for Professional Activities } \\
\end{array}$} \\
\hline \multicolumn{6}{|c|}{ Faculty Status Institutions $(\mathrm{N}=41)$} \\
\hline & \multicolumn{2}{|c|}{$\begin{array}{l}\text { Publication Required } \\
\text { for Promotion }\end{array}$} & \multicolumn{3}{|c|}{$\begin{array}{l}\text { Publication Required } \\
\text { for Tenure }\end{array}$} \\
\hline & Yes $(\mathrm{N}=28)$ & No $(\mathrm{N}=13)$ & Yes $(\mathrm{N}=24)$ & \multicolumn{2}{|c|}{ No $(\mathrm{N}=17)$} \\
\hline Support & $\% \mathrm{~N}$ & $\% \mathrm{~N}$ & $\% \mathrm{~N}$ & $\%$ & $\mathrm{~N}$ \\
\hline Long term leave & $93 \quad 26$ & $85 \quad 11$ & 9623 & 82 & 14 \\
\hline Short term leave & $93 \quad 26$ & 9212 & 9623 & 88 & 15 \\
\hline Mini leave & 7120 & 8511 & $71 \quad 17$ & 82 & 14 \\
\hline Travel funds & $100 \quad 28$ & $100 \quad 13$ & $100 \quad 24$ & 100 & 17 \\
\hline Research funds & $86 \quad 24$ & 8511 & $88 \quad 21$ & 82 & 14 \\
\hline Exchanges & $46 \quad 13$ & 385 & 4210 & 47 & 8 \\
\hline \multicolumn{6}{|c|}{ Non-Faculty Status Institutions $(\mathrm{N}=23)$} \\
\hline & \multicolumn{2}{|c|}{$\begin{array}{l}\text { Publication Required } \\
\text { for Promotion }\end{array}$} & \multicolumn{3}{|c|}{$\begin{array}{l}\text { Publication Required } \\
\text { for Tenure }\end{array}$} \\
\hline & Yes $(\mathrm{N}=1)$ & No $(\mathrm{N}=22)$ & Yes $(\mathrm{N}=0)$ & \multicolumn{2}{|c|}{ No $(\mathrm{N}=23)$} \\
\hline Support & $\% \mathrm{~N}$ & $\% \mathrm{~N}$ & $\% \mathrm{~N}$ & $\%$ & $\mathrm{~N}$ \\
\hline Long term leave & 0 & 327 & $0 \quad 0$ & 30 & 7 \\
\hline Short term leave & 0 & $\begin{array}{ll}55 & 12\end{array}$ & 00 & 52 & 12 \\
\hline Mini leave & 100 & $55 \quad 12$ & $0 \quad 0$ & 57 & 13 \\
\hline Travel funds & 100 & $95 \quad 21$ & $0 \quad 0$ & 96 & 22 \\
\hline Research funds & 0 & $45 \quad 10$ & $0 \quad 0$ & 43 & 10 \\
\hline Exchanges & 0 & $45 \quad 10$ & $0 \quad 0$ & 43 & 10 \\
\hline
\end{tabular}

activities to varying degrees through longterm leaves, short-term leaves, minileaves, travel and research funding, and professional exchanges (see table 1). Almost all the survey institutions provide travel funds, and most faculty status libraries offer research funding to assist librarians in meeting review criteria. Long- and short-term leaves are highly supported at libraries with faculty status. Although only one institution without faculty status requires publication for advancement, approximately half of those libraries support some type of leave, exchange, or research funding for professional activities. Exchanges are the least supported activity, but they are used fairly frequently, at similar rates, in both faculty and nonfaculty research libraries. Mini-leaves are used to support professional activities in small increments (one day to one week). Interestingly, such leaves are used at a higher rate where publication is not required for advancement or continuing appointment.
When asked if a program exists that orients librarians to the review process, 79 percent $(n=75)$ of the responding institutions replied that some form of orientation is in place. Sixty-three percent (n = 73) of the libraries have a mentoring program. In addition, several written responses show that informal arrangements exist for both mentoring and orientation to the review process.

\section{Rewards}

Rewards for serving as a mentor or contributing as a member of the library review committee are few. Generally, these activities are considered to be service to the institution and counted as part of the librarian's professional responsibilities. At 68 percent $(n=62)$ of responding institutions, no reward or compensation is given for serving as a mentor. However, such service is acknowledged when the mentor is considered for review. Review committee membership also receives no 
compensation or reward at 55 percent (n $=67$ ) of the responding institutions, but librarians often receive credit for this service when they are assessed.

Generally, promotion is acknowledged with some compensation. The granting of tenure/continuing appointment is normally rewarded through the librarian's status and reputation. However, 26 percent $(n=43)$ of the responding institutions support the award of tenure with some compensation.

\section{Discussion}

The status afforded to librarians on university campuses affects the structure and expectations in place for their appointment and advancement. Often librarians are given faculty rank and status in their appointment as members of the academic community. In fact, the use of faculty rank has grown in recent years since Thomas G. English's 1982 survey of ARL members. ${ }^{17}$

The structure of the review process is similar to the one described by Smith et al in a survey of tenured librarians in ARL member libraries. ${ }^{18}$ There is significant involvement in the peer review process by a library committee, the library director, and university administration. As peer review cases move through the university hierarchy, it is important that the library process be understood at each stage of the review. Candidates may need to explain or justify their contributions to a larger audience. The process employed for review of librarians and the documentation required should be equivalent to that used for other faculty on campus.

A number of distinctions exist in faculty status institutions for documenting and reviewing the performance of librarians. Faculty status institutions are much more likely to have elected review committees and university peer assessment. Moreover, there is greater emphasis on outside review, and by individuals unknown to the candidate, in these institutions.

In terms of criteria, there has been a greater emphasis on publication in the past five years, new opportunities for con- tributions in scholarship, and a trend toward service activities at the national level and away from local participation. ${ }^{19} \mathrm{~A}$ number of faculty status institutions require research activity for advancement, corroborating Ronald Rayman and Frank W. Goudy's finding that "Faculty status and tenure eligibility were key elements in establishing publication as a requirement for librarians." ${ }^{20}$

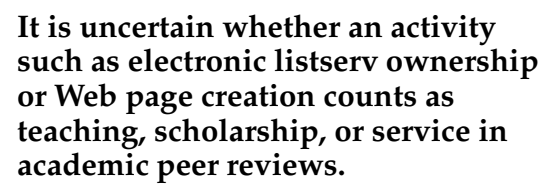

It is uncertain whether an activity such as electronic listserv ownership or Web page creation counts as teaching, scholarship, or service in academic peer reviews.

Although signs of a broadening definition of scholarship for librarians are beginning to develop, much uncertainty remains about how to assess contributions in electronic form, such as articles in electronic journals, Web page design, creation of subject-based guides to the Web, and so on. Blaise Cronin and Kara Overfelt found little reference in university or departmental documents to any special criteria being used to evaluate electronic contributions. ${ }^{21}$ Unsolicited comments from their study revealed that criteria such as quality of work, evidence of peer review, and status of publication venue are being used to evaluate both electronic and print contributions. It is uncertain whether an activity such as electronic listserv ownership or Web page creation counts as teaching, scholarship, or service in academic peer reviews. Such new activities are viewed by many as service rather than scholarship, believing that "technical work should not be afforded the same credit that rigorous research in one's field deserves."22 At the same time, what may be scholarship for one individual may be considered teaching for another, depending on the particular position and responsibilities within the organization.

The importance attributed to many activities in the review process is similar in both faculty and non-faculty-status institutions. Still, major refereed publica- 
tions and national service remain the most important elements of scholarship and service for librarians with faculty status. Other activities, such as editorship, grants, national papers, annotated bibliographies, book/software reviews, nonrefereed contributions, electronic publications, and Web activities, have gained greater acceptance, particularly in institutions without faculty status. This reflects a broader array of opportunities for contributions in nonfaculty libraries.

There is now increased support for meeting advancement and continuing appointment expectations through widespread assistance for professional travel, broad-based orientation to the review process, and elements such as release time and monetary support in survey institutions. Such support is a major key to success. In the area of scholarship, publication productivity for articles and book reviews by librarians having research support has been shown to be approximately four times that of librarians without such institutional support. ${ }^{23}$ As found in earlier studies, support is most often available at faculty status institutions or where publication for advancement is required. ${ }^{24}$ More information is needed on the use of professional leaves in terms of what activities are supported.

An effective acculturation and support program is essential in promoting the success of librarians. ${ }^{25}$ Although almost all the institutions surveyed have an orientation to the review process, approximately one-third of the administrators indicated that they do not have a mentoring program. In contrast, Rayman and Goudy found that two-thirds of their survey institutions provided no formal structure for mentoring in research and publishing for their librarians. ${ }^{26}$ This may be attributed to less emphasis on required publication during the period surveyed.

Mentoring is an important part of guiding the successful contributions of librarians, yet a majority of institutions provide no recognition for those who serve as mentors. Although some institutions report informal mentoring opportunities in certain cases, Roma M. Harris cautions against using mentoring of a few as a substitute for a good library-wide staff development program..$^{27}$ There are now other forums for communication such as dialog through the Internet via listservs, an important facet in fostering librarian growth and collegiality providing new opportunities for informal mentoring and networking. It is time to recognize the contribution of effective mentoring to the development of librarians. Efforts such as the peer support group program at Texas A\&M offer promise for improving the acculturation process for librarians on tenure track. ${ }^{28}$

\section{Conclusion}

Librarians today are being asked to contribute broadly to the institution and the profession in order to succeed in academic environments. Regardless of the status assigned, they are expected to provide and interpret information resources, participate in university and professional committee activity, and share scholarly and creative expertise. Performance expectations and the process used for evaluating performance are crucial elements in fostering and assessing the value of librarians on today's campuses. They form a critical environment for any advancement and continuing appointment system, governing service quality and success in the organization.

This study shows many similarities in the peer review structure among research institutions. However, institutional variances, especially those based on status, indicate the need for candidates, review committee members, and administrative officials within the library and the university to have a clear understanding of this process and the criteria used. If librarians are to remain successful, they will require that criteria be clear (that the expectations be communicated in an understandable manner to both librarians and university administration, the standards make sense, and the measurement be fair), comparable (librarians be treated in 
an equivalent manner to similar appointees on campus in terms of expectations and review process), and consistent (a message be promoted that is similar to the one provided by the annual performance appraisal and to other advice given on navigation through the assessment process). Librarians also will require the support structures to promote their ability to contribute. Although this has not often meant a similar schedule to the instructional faculty, it increasingly means new opportunities within the typical yearround calendar, including access to research and grant funds and support for involvement in campus, professional, scholarly, and creative activities. These opportunities need to be broadened to satisfactorily support the growing expectations for contribution in the university setting.

Regardless of the status given librarians, institutions will grow more homologous in their expectations and review processes for advancement and continuing appointment. Contributions to the profession and the scholarly record will increase in importance. At the same time, the definition of scholarship will continue to evolve in the academy and in the academic library profession, allowing a broader interpretation of what constitutes a contribution to the field. Something that was creative a few years ago, such as Web page design, can be considered commonplace today. ${ }^{29}$ How is this transition from the unique to the common dealt with in a rapidly changing environment?
There will be a rise in works of scholarship that go beyond the traditional definition of print on paper. As technology facilitates more collaboration and draws scholars together in new ways, there will be an increase in cross-disciplinary works and coauthorship with individuals from other fields. This will occur in both types of institutions, although there already is a greater willingness to accept a broader definition in the non-faculty-status institutions. As a result, standards for review of librarian contributions will change, perhaps not so much in the process used but, rather, in the criteria employed. New Pathways and the work of the ACRL Institutional Priorities and Faculty Rewards Task Force exhibit the change taking place in the definition of academic scholarship. Studies such as these will have a major impact on the future role of librarians in scholarship. ${ }^{30,31}$

There will be greater discussion of the peer review process on campuses, and librarians must have a voice in that dialog in order to help form meaningful outcomes. This is particularly true in situations where instructional faculty serve on librarian review committees. Even in environments where librarians are not faculty, it is important to develop an effective presence in campus discussions that will result in long-term benefits to the library and its staff. This will help ensure the pivotal role of the library on campus and the value of the librarian to learning.

\section{Notes}

1. Denise Magner, "A Scholar Provides an Intellectual Framework for Plans to End or Revamp Tenure Systems," Chronicle of Higher Education 43 (Feb. 1997): A10-A11. See AAHE Forum on Faculty Roles and Rewards (http://www.aahe.org/).

2. ACRL Institutional Priorities and Faculty Rewards Task Force, "The Redefining Scholarship Project: A Draft Report," College E Research Libraries News 58 (June 1997): 414-18. This report is based on Boyer's four functions of scholarship: discovery, integration, application, and teaching. Ernest L. Boyer, Scholarship Reconsidered: Priorities of the Professoriate (Princeton, N.J.: Carnegie Foundation for the Advancement of Teaching, 1990), 15-25.

3. Robert M. Diamond, Serving on Promotion and Tenure Committees: A Faculty Guide (Bolton, Mass.: Anker, 1994), 5-7; cited in Charles E. Glassick, Mary Taylor Huber, and Gene I. Maeroff, Scholarship Assessed: Evaluation of the Professoriate (San Francisco: Jossey-Bass, 1997), 54.

4. This article uses advancement and continuing appointment in a general sense to include promotion and tenure.

5. Developed in 1970 by Clark Kerr, the Carnegie system of classification groups together 
U.S. colleges and universities with similar missions and programs. Research I institutions receive a minimum of $\$ 40$ million in federal funding annually whereas Research II institutions receive a minimum of $\$ 15.5$ million in federal support. A Classification of Institutions of Higher Education (Princeton, N.J.: Carnegie Foundation for the Advancement of Teaching, 1994), vii, xix, 3-8.

6. Studies that have surveyed Carnegie Research libraries include: Betsy Park and Robert Riggs, "Status of the Profession: A 1989 National Survey of Tenure and Promotion Policies for Academic Librarians," College E Research Libraries 52 (May 1991): 275-89; Betsy Park and Robert Riggs, "Tenure and Promotion: A Study of Practices by Institutional Type," Journal of Academic Librarianship 19 (May 1993): 72-77; Charles B. Lowry, "The Status of Faculty Status for Academic Librarians: A Twenty-Year Perspective," College \& Research Libraries 54 (Mar. 1993): 163-72; Pamela S. Bradigan and Carol A. Mularski, "Evaluation of Academic Librarians' Publications for Tenure and Initial Promotion," Journal of Academic Librarianship 22 (Sept. 1996): 360-65. Some earlier studies of ARL institutions include: Thomas G. English, "Librarian Status in Eighty-Nine U.S. Academic Institutions of the Association of Research Libraries: 1982," College \& Research Libraries 44 (May 1983): 199-211; Ronald Rayman and Frank W. Goudy, "Research and Publication Requirements in University Libraries," College E Research Libraries 41 (Jan. 1980): 43-48; Priscilla Geahigan, et al, "Acceptability of Non-library Information Science Publications in the Promotion and Tenure of Academic Librarians," College E Research Libraries 42 (Nov. 1981): 571-75; John Cosgriff, Donald Kenney, and Gail McMillan, "Support for Publishing at Academic Libraries: How Much Exists?" Journal of Academic Librarianship 16 (May 1990): 94-97.

7. Judy Horn, "Peer Review for Librarians and Its Application in ARL Libraries," in Academic Libraries: Myths and Realities, ed. Suzanne C. Dodson and Gary L. Menges (Chicago: ACRL, 1984), 135-40.

8. Ibid., 138; Karen F. Smith, et al, "Tenured Librarians in Large University Libraries," College \& Research Libraries 45 (Mar. 1984): 91-98.

9. ACRL, "Standards for Faculty Status for College and University Librarians," College $\mathcal{E}$ Research Libraries News 8 (Sept. 1972): 210-12.

10. Park and Riggs, "Status of the Profession," 281.

11. Park and Riggs, "Tenure and Promotion," 75.

12. For example, see: Park and Riggs, "Status of the Profession," 282; Rayman and Goudy, "Research and Publication Requirements in University Libraries," 46-47; Geahigan et al, "Acceptability of Non-library Information Science Publications," 573-75; W. Bede Mitchell and L. Stanislava Swieszkowski, "Publication Requirements and Tenure Approval Rates: An Issue for Academic Librarians," College E Research Libraries 46 (May 1985): 249-55; Cosgriff, Kenney, and McMillan, "Support for Publishing at Academic Libraries," 96.

13. Bradigan and Mularski, "Evaluation of Academic Librarians' Publications for Tenure and Initial Promotion," 361-63; William K. Black and Joan M. Leysen, "Scholarship and the Academic Librarian," College \& Research Libraries 55 (May 1994): 229-41.

14. These standards define librarians with faculty status as individuals who exercise independent judgment, undergo a regular and rigorous peer review of their performance, participate in an academic form of governance, are eligible for membership in the faculty senate or equivalent government body, receive equitable compensation and benefits, are covered by a tenure policy equivalent to those of other faculty, are promoted in rank on the basis of academic proficiency and professional effectiveness, and are eligible for research leaves, research funding, and protection of academic freedom. See ACRL Academic Status Committee, "Standards for Faculty Status for College and University Librarians," College \& Research Libraries News 53 (May 1992): 317-18.

15. This figure is difficult to compare to earlier studies due to the different type of institutions surveyed and the size of the survey population. Lowry reported that 53 percent of Carnegie research and doctoral institutions combined had faculty status. Park and Riggs' 20 percent is based on 35 responses, a sample of 34 percent of all Carnegie research institutions. See Lowry, "The Status of Faculty Status for Academic Librarians," 165; Park and Riggs, "Tenure and Promotion," 73. ARL figures ranged from 35 percent reported by Rayman and Goudy, 46.1 percent by English, 46 percent by Lowry, and 30 percent by ACRL. See Rayman and Goudy, "Research and Publication Requirements," 44; English, "Librarian Status in Eighty-Nine U.S. Academic Institutions," 200-201; Lowry, "The Status of Faculty Status for Academic Librarians," 165; "Academic Status Survey," College \& Research Libraries News 42 (June 1981): 171.

16. Faculty rank includes instructor, assistant professor, associate professor, and professor. Examples of equivalent rank include assistant librarian, associate librarian, and librarian. Numerical rank includes titles such as librarian I, II, III, and IV. These categories were also used by English in "Librarian Status in Eighty-Nine U.S. Academic Institutions," 203, 208.

17. Ibid., 207. In 1982, English's survey of ARL institutions indicated that faculty rank repre- 
sented 23.6 percent of the ranks provided in the survey group. This is now 35 percent in the current survey. The number-holding equivalent rank was similar for both surveys.

18. Smith et al, "Tenured Librarians in Large University Libraries," 95.

19. This trend was also noted at the Auraria Library (University of Colorado at Denver) from 1976 to 1988. Kathleen Kenny, Linda D. Tietjen, and Rutherford W. Witthus, "Increasing Scholarly Productivity among Library Faculty: Strategies for a Medium-sized Library," Journal of Academic Librarianship 16 (Nov. 1990): 276-79.

20. Rayman and Goudy, "Research and Publication Requirements," 44.

21. Blaise Cronin and Kara Overfelt, "Brief Communication: E-journals and Tenure," Journal of the American Society for Information Science 46 (Oct. 1995): 700-703.

22. Lisa Guernsey, "Scholars Who Work with Technology Fear They Suffer in Tenure Reviews," Chronicle of Higher Education 43 (June 1997): A21-A22.

23. W. Michael Havener and Wilbur A. Stolt, "The Professional Development Activities of Academic Librarians: Does Institutional Support Make a Difference?" College \& Research Libraries 55 (Jan. 1994): 25-40.

24. Cosgriff, Kenney, and McMillan, "Support for Publishing at Academic Libraries," 96; English, "Librarian Status in Eighty-Nine U.S. Academic Institutions," 207; Lowry, "The Status of Faculty Status for Academic Librarians," 167.

25. W. Bede Mitchell and Bruce Morton, "On Becoming Faculty Librarians: Acculturation Problems and Remedies," College \& Research Libraries 53 (Sept. 1992): 379-92.

26. Rayman and Goudy, "Research and Publication Requirements," 46.

27. Roma M. Harris, "The Mentoring Trap," Library Journal 118 (Oct. 1993): 37-39.

28. Jeannie P. Miller and Candace R. Benefiel, "Academic Librarians and the Pursuit of Tenure: The Support Group As a Strategy for Success," College $\mathcal{E}$ Research Libraries 59 (May 1998): $260-65$.

29. Jeffrey R. Young, "Wave of the Future or a Waste? UCLA Requires Web Page for Every Class," Chronicle of Higher Education 43 (Aug. 1997): A21-A22.

30. AAHE Forum on Faculty Roles and Rewards (http://www.aahe.org/).

31. ACRL Institutional Priorities and Faculty Rewards Task Force, "The Redefining Scholarship Project," 414-18. 